\title{
Circulating in Commonplaces: Harriet Beecher Stowe's Celebrity Status in the Netherlands
}

Laurens Ham

\section{(2) OpenEdition \\ Journals}

Electronic version

URL: https://journals.openedition.org/ejas/12671

DOI: 10.4000/ejas.12671

ISSN: 1991-9336

Publisher

European Association for American Studies

\section{Electronic reference}

Laurens Ham, "Circulating in Commonplaces: Harriet Beecher Stowe's Celebrity Status in the Netherlands", European journal of American studies [Online], 13-2 | 2018, Online since 28 June 2018 connection on 08 July 2021. URL: http://journals.openedition.org/ejas/12671 ; DOI: https://doi.org/ 10.4000/ejas. 12671

This text was automatically generated on 8 July 2021.

Creative Commons License 


\title{
Circulating in Commonplaces: Harriet Beecher Stowe's Celebrity Status in the Netherlands
}

\author{
Laurens Ham
}

1 In 2015 and 2016, the journals Critical Survey and Comparative American Studies each published a special issue on nineteenth-century transatlantic celebrity, each journal taking its cue from the 2014 University of Portsmouth conference Celebrity Encounters: Transatlantic Fame in Nineteenth-Century Britain and America. Whereas the conference title suggested a scope limited to exchanges between Britain and the US, the titles of the journal issues explicitly promise a comparison between American and European celebrity: Celebrity Encounters: Famous Americans in Nineteenth-Century Europe and Transatlantic Celebrity: European Fame in Nineteenth-Century America, respectively (emphasis LH). The introductions to both issues also mention this supposed European perspective, but all twelve actual articles compare the US to Britain only, creating an erroneous impression of ubiquitous celebrity while focusing on a single European nation.

2 This academic mono-fixation is far from unique. ${ }^{1}$ Studies of transatlantic cultural encounters often neglect the non-Anglophone parts of Europe, which results in generally flattering interpretations of the role of American writers as celebrities in the nineteenth-century European book market. It is clear, after all, that Britain is far from representative when it comes to the institutional and ideological literary situations in Europe as a whole: in the 1850s, the UK had the most commercialized and professionalized literary field in the world. Fred Inglis describes that this has been the case since the mid-seventeen hundreds, when England began producing commodities like books, clothes, and paintings on a hitherto unseen scale (Inglis 39-40). The first bestselling authors in the US date from around a century later; examples include Susan Warner (The Wide, Wide World, 1850), Harriet Beecher Stowe (Uncle Tom's Cabin, 1852), and Henry Wadsworth Longfellow (The Song of Hiawatha, 1855). American literature therefore did not become "mass phenomenon" until the 1850s (Dowling 1-2), and we 
might assume that bestselling authors in smaller, non-English-speaking European areas did not rise to prominence until even later.

In this article, I wish to investigate American celebrity culture in one of these smaller countries: the Netherlands. I will focus on who was arguably the biggest literary star of her time, Harriet Beecher Stowe, an international record breaker both in sales and in media presence. She was also the American writer with the largest number of reviews in nineteenth-century Dutch media: 60 reviews in total, James Fenimore Cooper coming in second with 58 articles (Riewald and Bakker 10-11). In several recent studies, Stowe's celebrity is presented as a "European," "transatlantic" phenomenon (Kohn, Meer and Todd; Weber 94). ${ }^{2}$ But to what extent can Stowe be considered an actual celebrity in the Netherlands during the second half of the nineteenth century? Were the amount and the contents of the textual representations of her authorial figure anywhere as impressive as the number of books that she sold? While the phenomenal success of Uncle Tom's Cabin often gets mentioned in studies about Dutch book culture of the mid-1850s, Stowe's celebrity status in this part of Europe has never been studied before.

4 Focusing on the Dutch institutional and ideological situations, I aim to show that although textual representations of Harriet Beecher Stowe did indeed circulate around 1850 , this circulation did not take on the massive scale that seems necessary for a celebrity status. Whereas Uncle Tom's Cabin was, by Dutch standards, an incredible success, journalists were only marginally aware of the authorial figure of Stowe herself. Journalists and writers generally acquired knowledge about her life and work through secondary sources such as British and American newspapers and letters, and the information obtained was often superficial at best. From an ideological point of view, the phenomenon of literary celebrity was a controversial one in the nineteenthcentury Netherlands. Longer articles in literary periodicals start criticizing and ridiculing Stowe and her works even as early as 1854, only a year after her successful entrance onto the Dutch literary market. Such disparaging comments seem to be indicative of a certain aversion to celebrity, and suggest that there were several social debates going on in the Netherlands that hampered the emergence of a so-called "celebrity society."

\section{Measuring Celebrity?}

Before we can discuss the case of Stowe's celebrity, we need to address the complex matter as to whether celebrity can be measured at all. How are we to determine the scale of Stowe's success in the Netherlands? This matter touches upon several debates in celebrity studies on how one is to define and demarcate celebrity. One could for instance wonder whether writers who were active before the period of mass media could be labeled celebrities at all, given the fact that media channels only reached small audiences. As the editors of Celebrity Authorship and Afterlives in English and American Literature (2016) euphemistically write: "Opinions differ as to the origin of celebrity" (Franssen and Honings 4). Many scholars agree that a recognizable European celebrity culture had been established by the early nineteenth century (e.g., Finnerty and Rosenquist 1), but some authors situate the origin of a celebrity culture as early as classical antiquity (e.g., Visser 6). 
6 These divergent interpretations can be traced back to two different but deeply intertwined debates. First of all, Franssen and Honings rightly state that it makes all the difference whether or not one chooses to equate the decidedly older phenomena of "fame" or "renown" with the more modern concept of "celebrity" (4). According to Braudy, for instance, notions of fame and renown date back to at least Alexander the Great, but Schickel among others asserts that the concept of celebrity must be distinguished from these older phenomena (Franssen and Honings 4). Although in the centuries before the eighteenth, individuals could certainly achieve renown because of (a perception of) their great merit, such people did not win celebrity, that mass-scale kind of popularity that is detached from one's personal qualities (Inglis 4-5). A celebrity, after all, is often interpreted as "a person who is known for [her] wellknownness," to quote Daniel J. Boorstin's seminal definition (Boorstin 217). This question of definitions is closely related to a second issue, namely whether one interprets celebrity merely as a cultural phenomenon or also as a social-economic one. Inglis seems to favor the latter position. You could only become known for your wellknownness, he suggests, in societies where there were certain social-material "underlying forces" that "composed celebrity"; he describes the forces at play in eighteenth-century London: "[F]irst, the new consumerism of eighteenth-century London, ... second, the invention of the fashion industry [and] third, the coming of the mass circulation newspaper" with "its gossip columns" (Inglis 9). Robert van Krieken agrees with this interpretation: he states that several social-economic tendencies in modernizing societies, such as individualism, the rise of the mass media, and democratization are needed for a phenomenon as celebrity to appear (Van Krieken 16).

7 To emphasize the importance of socio-economic conditions, Van Krieken proposes exchanging the metaphor of a "celebrity culture" for that of a "celebrity society." The concept of culture, he claims, is "generally not very adept at capturing issues or concerns that go beyond values, mores, attitudes, forms of behaviour, cognitive orientations and ways of life, to understand the social, political and economic structures as well as the institutional foundations of what we experience as "celebrity"' (Van Krieken 2). The term celebrity society still does not guarantee a reliable measurement of celebrity in a specific community, but it does serve as an apt warning that gaining a better insight into celebrity requires us to look further than individual mentions in (high) literary culture: we should also take the author's popularity, the general developments in media, and the socio-political situation into account. That is why I will follow Van Krieken's use of the term.

\subsection{Stowe's Celebrity in Nineteenth-Century Britain and the US}

8 The first half of the nineteenth century saw the introduction of radically new printing technologies in the US and in Britain. In 1814, The Times was the first newspaper to be printed on steam-driven presses, and the introduction of the rotary printing press in the US in 1833 sped up the printing processes for newspapers, magazines, and books spectacularly (Van Krieken 40).

9 Soon after its first printing, Uncle Tom's Cabin became particularly associated with the new, unparalleled printing possibilities of the Industrial Age. In 1852 and 1853, many journalists repeated the story that multiple modern presses had to run day and night to meet the incredible demand for the book. One typical instance can be found an 
unsigned review of Uncle Tom's Cabin in Putnam's Monthly, which Marcus Wood claims was written by Charles Frederick Briggs (Wood 145-146):

The book was published on the 20th of last March, and on the 1st of December there had been sold one hundred and twenty thousand sets of the edition in two volumes, fifty thousand copies of the cheaper edition in one, and three thousand copies of the costly illustrated edition. The publishers have kept four steam-presses running, night and day, Sundays only excepted, and at double the ordinary speed, being equal to sixteen presses worked ten hours a day at the usual speed. ("Uncle Tomitudes" 98)

10 According to the reviewer, Uncle Tom could only have become such a success thanks to the modern technological infrastructure of "our steam-presses, steam-ships, steamcarriages, iron roads, electric telegraphs, and universal peace among the reading nations of the earth" (98). He concluded by saying that the book's extraordinary dissemination brought the author incredible financial success: "They have paid to the author twenty thousand three hundred dollars as her share of the profits on the actual cash sales of the first nine months" (98-99).

11 The source of these sales figures in the US was most likely the book's American publisher, John P. Jewett, who distributed several advertisements. An early ad (The New York Independent, May 20, 1852) mentions the number of 50,000 sold copies in eight weeks, and the book jacket of the subsequent "Edition for the millions!" stated that 300,000 copies had been distributed in a year's time. ${ }^{3}$ These figures are very hard to verify, as Claire Parfait has shown: every single number can be traced back to Jewett himself (Parfait 99-100). To this day, academic sources reproduce the figures of 300,000 American copies sold in the first year-even the story of the printers running day and night continues to be mentioned (e.g., Ammons 55).

Even more remarkable, and less contested, is the claim that no less than 1.5 million copies were sold in Britain in 1852. Retracing the source for this figure through references and quotations, I have found that there is a single source for this number: Sampson Low, Stowe's British publisher. Low was quoted by Charles E. Stowe, one of Stowe's sons, in his The Life of Harriet Beecher Stowe, which was published by Low's company in 1889. In the book, Low is quoted saying: "After carefully analyzing these editions and weighing probabilities with ascertained facts, I am pretty confidently to say that the aggregate number of copies circulated in Great Britain and the colonies exceeds one and a half millions" (Stowe, The Life 190). The Stowes and their publishers seem to have contributed considerably to Harriet Beecher Stowe's celebrity this way. One of the most significant aspects of her fame in the nineteenth century, after all, was the fact that she was reputedly the bestselling author of her time. The sole source for this claim is the author's son quoting the author's publisher, arguably not the most neutral of sources.

Other family members of the author, such as her brother Henry Ward Beecher and her husband Calvin Ellis Stowe, also helped fashion her celebrity status over the course of the 1850s. In 1853, they accompanied Stowe on a tour to Britain, where she was invited by the Glasgow Ladies' Anti-Slavery Society and the Glasgow Female New Association for the Abolition of Slavery (Robbins). She traveled through Scotland and England for several months and attracted huge numbers of fans. Less famous is the second part of her journey, which led through Paris, Switzerland, and Germany and during which the reception was far less enthusiastic. She did not visit the Netherlands, which was perhaps too marginal a country for such a promotional tour. 

backseat to the dominant social norms of the time, as it was considered inappropriate for women to speak in public (Hedrick 232-250). Her brother and husband were therefore the ones who did the talking wherever she visited. Stowe was therefore, in Amanda Adams's words, "seen and not heard" by the large masses who came to meet her (Adams 45-46). Stowe violated this rule only once: "In the private home of the Duchess of Sutherland, Stowe did address some women in a room, separate from the men, including her own husband and brother" (51-53). Calvin and Henry, however, did contribute to her fame by responding extensively to the praise sung by her male hosts often politicians or clergymen. All these laudations and responses were reprinted in Sunny Memories of Foreign Lands (1854), Stowe's account of her European journey. She used this travel memoir both to give her own interpretation of her public popularity and to reproduce influential opinions expressed by others (Robbins).

is likely that Stowe did have some opportunities to present herself to the public, but that she had to do so carefully in order to not transgress the rather strict gender norms. According to Michael Newbury, Stowe's constant emphasis on Christian martyrdom, both for herself and for Uncle Tom protagonists Tom and little Eva, is closely connected to the author's own views on female celebrity:

For Harriet Beecher Stowe, to imagine Christian martyrdom as the process of moral reformation was to imagine that martyrdom taking place on stage, whether that stage be Eva's bedroom or the lecture halls of London.... In short, Stowe imagines in Eva the domestic celebrity as Christian martyr but, simultaneously, imagines martyrdom through (and figuratively mediates the differences between) the conditions and economics of antebellum slavery and celebrity. (Newbury 97)

The British feminist and sociologist Harriet Martineau described Stowe as a martyr-like figure, a role Martineau "consistently saw as the very opposite of a celebrity": whereas Martineau considered celebrities as selfish, she thought Stowe devoted herself to the good cause (Adams 33). From this point of view, Stowe succeeded in presenting herself as a writer who was known not for her well-knownness but for the high moral standards she maintained, both for her characters and for herself. According to Blake, many journalists in the mid-1800s believed that celebrities could fulfill such exemplary societal functions (Blake 55-57).

Over the course of the nineteenth century, Stowe and the characters of her most famous novel found their way ever more easily into popular culture. The early 1850 s saw the production of the first puzzles and card games featuring (characters from) the novel, particularly in Britain. As manufacturing techniques and (color) printing became cheaper and cheaper in subsequent decades, the production of "Tomitudes" (as these commodities were soon called) increased. Until well into the twentieth century, the Western world was awash with Uncle Tom dolls, board and card games, ash trays, porcelain figures, postcards and the like. ${ }^{4}$ This exposed a spectacularly large audience to the novel's themes, ideas, and characters-although one wonders whether these Tomitudes increased Stowe's celebrity. Her picture seems to have rarely been included in these commodities. I was able to find only two Tomitudes-both from the 1890s-that feature an image of Stowe herself: a "Representative Americans" calendar from 1894 includes a color illustration of Stowe; and on a poster for a stage adaptation, probably from the late 1890s, we can see Abraham Lincoln flanked by a former enslaved person and a small portrait of Stowe. ${ }^{5}$ Media innovations, better infrastructure, and commercialization definitely contributed to the making of one of the most hyped 
novels in the English language. It is debatable whether this resulted in a star status for Stowe herself: although she clearly found fame in the English-speaking world, it was her work that attracted the most attention.

\subsection{Stowe's Celebrity in the Nineteenth-Century Netherlands}

Adopting a purely cultural interpretation of celebrity, we can see several signs of the existence of a general culture of fandom and celebrity in the Dutch nineteenth century as well. Rick Honings's pioneering research into Dutch nineteenth-century celebrity authorship, for instance, has opened up a substantial amount of odes, eulogies, adaptations, and other signs of fan and fame culture in the Netherlands. However, Honings writes practically nothing about the book market, sales figures, or mentions in the mass media. The Dutch literary world he describes is a fairly small one, with a core of a few dozen male writers, clergymen, politicians, and scholars-not exactly the massmedial world we can see in Britain and the US in the same period.

In the slipstream of the 1853 translation of Unce Tom's Cabin (infamously titled De negerhut, which can be literally translated as The Negro Hut), several other international Tom-related works were translated into Dutch. Among these, there was a children's adaptation, A Peep into Uncle Tom's Cabin (Aunt Mary, 1853; translated the same year), John Passmore Edwards and Frederick Douglass's Uncle Tom's Companions: Or, Facts Stranger Than Fiction (1852; translated 1854), and the French dramatic adaptation La Case de l'oncle Tom by Dumanoir and d'Ennery (1853; translated 1854). There were also original Dutch political pamphlets, with titles that referred to Stowe's novel to attract attention. Examples include J. Wolbers's De slavernij in Suriname, of Dezelfde gruwelen der slavernij, die in de 'Negerhut' geschetst zijn, bestaan ook in onze West-Indische koloniën! ("Slavery in Surinam, or: Those Same Horrors of Slavery Depicted in Uncle Tom's Cabin Also Exist in Our West-Indies Colonies!," 1853).

These were publications in the margins of literary culture, but Uncle Tom was also mentioned, praised, and adapted by respected writers. In 1854, Dutch poet Bernard ter Haar published a poetic re-interpretation of a well-known Uncle Tom scene: Eliza's flight over the ice. Twelve years later, he lauded Stowe in a poem. Stowe was called a celebriteit (a very literal and highly unusual translation of "celebrity") in Elise van Calcar's novel Kinderen der eeuw (1872-1873). Uncle Tom was mentioned in several key Dutch novels of the period, such as Jacob van Lennep's Klaasje Zevenster (1866), Cécile de Jong van Beek en Donk's feminist classic Hilda van Suylenburg (1897), and-famouslyMultatuli's absolutely canonical Max Havelaar (1860), which was clearly inspired by Stowe's engaged sentimentalism (Ham). An engraving of Stowe's portrait has been preserved in the collection of Multatuli's books and objects. ${ }^{6}$ From a cultural vantage point, we might assume that all these references and instances of praise are indicative of Stowe's celebrity in the Netherlands, and of the bestseller status of her best-known novel. However, all Dutch adaptations and literary works mentioning Stowe or Uncle Tom are from fellow (literary) authors, meaning that they cannot provide us with any insight into the mass-medial dissemination of representations of either the writer or the novel.

21 For a better understanding of the reception of Stowe in the Netherlands, it seems necessary to reckon with the institutional and medial boundaries of the time. A massive, centralized book distribution may have been hampered by the fact that Dutch 
was an official language in three culturally and institutionally distinct geographic regions: the Netherlands, Flanders, and the Dutch East Indies. ${ }^{7}$ In the mid-1800s, these regions did not engage in particularly intense cultural exchange, as is attested to by the fact that between 1852 and 1855, each of these areas published its own translation of Uncle Tom. Another important aspect curbing the development of a Dutch mass-media landscape was the fact that the average novel appeared in an edition of a mere 300 copies. Uncle Tom's Cabin managed to surpass this average in spectacular fashion, selling 18,000 copies in four years (Huisman 60-61), but this was highly unusual. Books were mainly bought by well-to-do readers: modern steam presses were still relatively rare in the Netherlands of the 1850s, making books and newspapers quite expensive. The first edition of the 1853 De negerhut translation, for instance, cost almost 8 guilders (about 95 dollars today), compelling a disappointed journalist to write: "We regret that the price is once again so high that common people will surely not get hold of this book" (Van der Meulen 136).

\subsection{Dutch Media Discourse (I): Newspapers on Stowe's 1853 European Tour}

22 We have seen that the Dutch book market did not facilitate a smooth distribution of Stowe's works to broad layers of society, and when we take a closer look at the newspaper coverage of Stowe's 1853 European tour, it becomes clear that Dutch media did not further the creation of a Stowe cult in the Netherlands either. Dutch newspapers did cover the tour rather extensively, but the articles differed from the reports in British and American publications in interesting ways. Newspapers in Britain and the US provided many detailed reports on Stowe's public performances, and not always in a respectful tone. The popular-and sometimes populist-New York Herald, for instance, published several reports that were decidedly ironic. Stowe's visit to the London Almack's Assembly social club was portrayed with a jibe: the anonymous correspondent wrote rather mockingly about the pompous lectures by the well-known abolitionist Joseph Sturge and Stowe's husband Calvin, and about the large mass of curious people who had gathered to take a peek at Stowe in real life. Stowe herself is pictured in a rather stereotypical way as well:

In exterior manner and deportment, Mrs. Stowe bore with becoming modesty and propriety the show made of her. She is much better looking than the daguerreotypes and engravings in the shop windows represent her to be. In her pictures it is a figure of a coarse, fat, vulgar, brazen-faced woman; but she is quite the reverse in fact, and in paleness and elegance of figure, joined with ease and selfpossession of deportment, quite an American lady.

What, however, her inward emotions must have been at seeing all this Uncle-Tom foolery-how all this unmeaning, silly incense and insincere flattery worked upon her vanity-can be known to no human being. She at all events had the skill and the tact to conceal every emotion. ("Affairs in Europe")

It must be noted that although such articles were far from flattering, they did include elaborate reflections on Stowe's lectures and on the craze that surrounded her. The same holds for the British reception: British newspapers provided their readers with detailed reports of Stowe's European tour, and they discussed Stowe's authorial position in long, sometimes critical reviews (Fisch 102-107; Robbins 77). The 1853 tour is also often covered by Dutch national and regional newspapers, but the number, tone, 
and content of the Dutch pieces are quite different from the British and American ones. expensive and thereby exclusive meant that there were relatively few readers. In the mid-1850s, after the formal declaration of the freedom of press in 1848, this tax system impeded the professionalization and growth of a modern press in the Netherlands, a situation that could only improve after the system was abandoned in 1869 (Janse 211-249). In the 1850s, Dutch newspapers did not have the time or the money to send reporters to Britain, let alone to the US, making journalists completely dependent on foreign news sources when it came to international stories about events such as Stowe's European tour. Whenever Dutch newspapers in 1853 actually refer to their sources, these sources are (usually unspecified) letters or international news media. This tendency can be discerned both in the larger newspapers produced in the bigger cities (the Amsterdam Algemeen Handelsblad, the Rotterdam Nieuwe Rotterdamsche Courant), and in smaller regional papers:

The famous writer of Uncle Tom's Cabin, Mrs Harriet Beecher Stowe, will shortly be expected in London, according to a letter she has written herself. (Groningen Courant, February 8, 1853)

Letters from the United States report that Mrs Harriet Beecher Stowe, author of Uncle Tom's Cabin, will set off with the steamship Glasgow for the journey to England from New York on the $26^{\text {th }}$ this month. (De Nederlander, March 14, 1853)

A letter from New York announces that Mrs Harriet Beecher Stowe, the author of Uncle Tom's Cabin, lies severely ill in that city. (Arnhemsche Courant, April 9, 1853)

Not only are these messages often strikingly contradictory, they are mostly utterly incorrect as well: for example, the steamship she traveled with is inaccurately called Glasgow instead of Canada (Hedrick 233). Moreover, the constant repetition of commonplace catchphrases such as "author of Uncle Tom's Cabin" is telling: it suggests that Dutch readers were not so acquainted with Stowe that they were expected to immediately recognize her name. The labels that newspaper use are also generally superficial and unoriginal. Stowe is constantly called "famous" or "celebrated" (Leeuwarder Courant, February 8, 1853; Nieuwe Rotterdamsche Courant, March 7, 1853), and her tour is described as a "great success" or a "victory march" (Nieuwe Rotterdamsche Courant, April 30, 1853; Provinciale Drentsche en Asser Courant, April 30, 1853). The practical problems that seemed to afflict the Dutch news structure even led to several contradictory articles being published in the same newspaper, and to an already rectified rumor about Stowe's death being reproduced two months later in a Dutch Indies newspaper. ${ }^{9}$ 
27 All in all, Dutch news articles about Stowe's 1850s tours suffered from many flaws: the information was contradictory, second-hand, and often blatantly wrong because of the lack of money and possibilities for original research, although there was little improvement to these issues when Dutch journalism slowly started to grow and professionalize in later decades.

\subsection{Dutch Media Discourse (II): Magazines on Stowe's Celebrity Status}

One would expect the situation in literary and cultural magazines to be better: as they were less dependent on quick results, authors in such magazines could be expected to have had more opportunities to produce more profound articles. In some respects, the discourse on Stowe's celebrity status in literary and cultural magazines is similar to how Dutch newspapers write about the author. The same commonplaces are repeated again and again: "the honored author of Uncle Tom's Cabin" ("De Slavernij" 761); "the famous author of Uncle Tom's Cabin" ("De Meibloem" 700); "Mrs Beecker [sic] Stowe, the author of Uncle Tom's Cabin, whose star is currently rising" (YY 94). But since these texts are quite long compared to the very brief newspaper articles, they also give journalists and reviewers a chance to somewhat expound upon Stowe's authorship and her popularity-making such sources far more informative with regards to Stowe's celebrity status in the mid-nineteenth century Netherlands. In addition, an investigation of these magazines shows us that Stowe's authorial status in the Netherlands was rather problematic in an ideological sense as well: not only her popularity (as a female writer), but also her overt Christianity led to all kinds of discussions and controversies.

What stands out in the magazine articles is the constant emphasis on Stowe's work as an emotional (as opposed to a rational-rhetorical) effort. In the literary magazine $D e$ Gids, J. C. Zimmerman writes:

Uncle Tom's Cabin, a book that, in spite of its shortcomings, has created more sympathy for the emancipation of slaves than the hundreds of more or less erudite treatises and pamphlets, philosophical and philanthropical, that have been published about this topic before.

Would this result not be due to the fact that Mrs Stowe rightly pulled the string of feeling, instead of invoking reason? (Zimmerman 141; emphasis LH)

In the somewhat sentimental Dutch literary culture of the nineteenth century, an appeal to emotions was not remarkable in itself, but the direct political effects of Stowe's use of sentimental fiction were observed with admiration. Quite often, magazine articles directly linked this emotional character to Stowe's gender or to her Christian conviction, such as in an article by the pseudonymous author Spiritus Asper en Lenis in the Christian magazine De Tijdspiegel (1853). This text presented Uncle Tom to Dutch audiences very early, discussing the novel before the Dutch translation was even published. The review frames the novel as an international success by mentioning several of the book's international versions: "La Cabane de l'oncle Tom. / La Case du père Tom. / De Negerhut. / Onkel Toms Hütte." The article's motto is a Virgil quote, resolutely positioning the novel in a classical fame culture: "Fama.... / Mobilitate viget, viresque acquirit eundo. / Parva metu primo, mox sese attollit in auras." (Translation: "Fame... by exerting her agility grows more active, and acquires new strength by 
progressive motion: small at first through fear, soon she shoots up into the skies" (Virgil 16)). This quote would at first seem to suggest that Stowe would grow ever more comfortable in her celebrity role, but Spiritus focuses on something else:

As can be assumed from what we know about the author's biographical circumstances, it must not have been her main purpose to 'be a hit' or to 'cause an uproar.'-She surely wished in the first place to arouse the sympathy, the compassion of her compatriots, and to more indirectly affect the pending slavery question. If we are correct, this Christian and therefore humble woman shall first be surprised, then astonished, later shy and somewhat downcast by the amazing impression her scenes have made; first in the West, then in the East, and now already up North. (Spiritus Lenis en Asper 184; italics in original)

One the one hand, Stowe is taken very seriously here: she is not only connected to Virgil, but also to Julius Caesar: "[W]e may say about [her] what a thousand times has been said about Julius Caesar-: he came-she came-he saw-she wrote-and conquered" (185). But at the same time, a lot of emphasis is put on her social position as a "modest clergyman's wife" and "a female preacher for the oppressed people" (186-187). Stowe is permitted to act as a benevolent celebrity, but many Dutch reviewers suggest that she can only do so when she respects the gender norms of modesty and piety.

These gender norms are made explicit by J. J. van Oosterzee, a highly popular preacher and author at that time, in an 1867 lecture: "The Woman and the New Literature." Oosterzee mentions four successful women writers: "George Sand, the talent without conscience; Harriet Beecher Stowe, moral liberator of the slaves; Frederika Bremer, good genius of domestic life; and Mrs Bosboom Toussaint, Christian historical novelist of the Netherlands." The fact that George Sand, the least religious of these authors, is called a "talent without conscience," is illustrative of Oosterzee's moral and social stance on women as writers: "She should never sacrifice her feminine duties for her authorship." According to Oosterzee, women writers would do better not to interfere in the public domain, but should restrict themselves to "the subjective field" of the domestic domain. They should at all times be "truly feminine, truly patriotic, and truly pious" ("Binnenland").

For many journalists of Christian and conservative magazines of the mid-1850s, Stowe matches this description perfectly: her emotional appeal to the Christian sympathy of her readers is praised and considered a prime example of good female authorship. Soon after 1853 (the publication year of the Dutch translation of Uncle Tom's Cabin), however, liberal authors in a magazine such as De Gids start satirizing Stowe's popularity: journalists mock both Stowe herself and the many adaptations and imitations of her most famous work, because these are said to present the issue of slavery in an exaggerated and insincere way.

In one of the first De Gids articles on Uncle Tom, H. J. Schimmel suggests that the novel is far from perfect in an aesthetic sense, but that the lack of organization gives the work a "virginal freshness" that lets the reader forget the literary flaws. Schimmel bonds with his liberal reader by suggesting that this reader-just like himself-is untouched by the "excessive" honor conferred upon Stowe: "[Y]ou do not agree with the thousands of people, who sing her praises; ... you may feel only disapproval for the passionate adoration that she receives" (Schimmel, "Blikken" 28). In the following years, De Gids publishes increasingly critical reactions to Stowe's popularity. Schimmel for instance writes that his fellow author J. J. ten Kate "seems like so many people to idolize 
[Stowe's] work-it has become fashionable to shed tears of sympathy over the black slave" (Schimmel, "Holland" 137). By the end of the 1850s, conservative magazines such as Vaderlandsche Letteroefeningen also start criticizing Stowe's popularity, mainly because of the endless uninspired Uncle Tom imitations:

Since Mrs BEECHER STOWE, with her ideal-type negro, managed to win the sympathy of white people for the poor race that they have oppressed so long and so violently, and that they, notwithstanding this sympathy, kept oppressing just as hard;--slaves have become the favorite subject of novels and stories and dramas, in poetry and prose. ("Schaduwbeelden uit Suriname" 223)

Although articles like these illustrate not so much an aversion to the figure of Stowe herself as a disapproval of her imitators, it becomes clear that these authors sometimes consider Stowe herself a part of the problem. One article explicitly connects Stowe to a "typically American," overzealous cultural tradition of female writers (the text mentions Stowe, Elizabeth Wetherell, and Amy Lothrop) who adopt a "pathological pietism" as a reaction to America's "abundant pressure of material development, material demands and worries" (Carpentier 642). Carpentier seems to interpret both materialism (and perhaps celebrity, although he does not make this explicit) and devout piety as "extreme," utterly un-Dutch phenomena.

Some liberal authors go further in their disapproval of Stowe's explicitly Christian authorship. A cynical "ode" to Stowe by the pseudonymous author Leo points up the possible perverse results of Stowe's social critique, with its (according to him) racist undertones:

Virtuous Mistress Stowe, who tells us so touchingly how the simple godless heathen Tom proudly stands up against the tyrant, who torments him, and how the converted Tom, the patient Christian Tom, bends his back in pious, god-fearing humility for his master and lets himself be tortured to death in quiet resignation to God's will! Virtuous Mistress Stowe, tender-hearted housewife, who with one hand delivers blows to your compatriots, and with the other hand holds a cookie out to them to numb the pain:-who with one hand chastises the slave owners and traders and then, compassionately, rubs salve on the wound, by showing them the way to get patient, pious, resigning slaves who will work themselves to death, by the use of an unfailing household remedy: by conversion, by teaching them Christianity! (Leo 102)

This stinging criticism shows that Dutch reactions to Stowe's work may have been influenced by ideological controversies. Where many authors in conservative and Christian magazines such as De Tijdspiegel and Vaderlandsche Letteroefeningen accepted Stowe's popularity exactly to the extent that it was related to her religious convictions (and as long as she did not violate the gender rules), liberal authors felt provoked by those very same convictions.

Of course, Stowe was also the center of much controversy in the US: the large production of anti-Tom novels in the American South indicates the deep ideological fault lines that would culminate in the Civil War ten years later. One might say that the commercial, depoliticized manifestation of Stowe and Uncle Tom-symbolized in the 1850s European tours by the highly effective book campaigns by Stowe's American publisher Jewett, and the Tomitudes-was her only uncontroversial manifestation in the English-speaking world. In the Netherlands, Tomitudes seem to have been absent, and although Uncle Tom was indeed a huge success, there was no massive and effective book campaign such as Jewett's. And when Sunny Memories of Foreign Lands was translated into Dutch, the introduction was left out, meaning that all laudations by 
clergymen and the responses by Stowe's brother and husband were unavailable to Dutch readers (Stowe, Herinneringen).

\section{Conclusion}

The above findings and analyses provide us with a plethora of reasons to doubt the existence of Harriet Beecher Stowe's celebrity status in the Netherlands. Institutionally and materially, the Netherlands did not develop a somewhat modern press or book market until in the late nineteenth century. This situation was not favorable to the development of a "celebrity society," to use Robert van Krieken's terminology. Compared to other Dutch and American writers, Stowe was discussed in the Dutch media fairly often, but always either in a superficial or in a negative way. The longer magazine articles, which were all published in media outlets with distinct ideological positions, were not consistent in their praise for Stowe's work or for her as an authorial figure. In the Christian milieu, she was uncontroversial and respected, although journalists in this group were not generally positive about female celebrities challenging gender norms. Liberal authors mocked and criticized Stowe's explicit Christian positioning soon after her work was introduced to the Dutch literary world. It is important to realize that antifandom is not necessarily contradictory to celebrity (Claessens and Van den Bulk): in Britain and the US, Stowe's media coverage was far from univocally positive as well, but this did not hamper the formation of a Stowe cult. In the Netherlands, however, the culture as a whole seemed suspicious of the phenomenon of (female) celebrity.

With this in mind, it becomes quite problematic to continue to adhere to the label of a nineteenth-century "transatlantic celebrity" if any definition of it is to include nonEnglish-speaking countries such as the Netherlands. The possibilities for celebrity societies arising in other European countries, such as Germany, France, or Spain, are likely to have been utterly different wherever one looks, affected by different social, cultural, economic, and technological forces. The focus on US-Britain interactions that has dominated the field up until now has skewed our notions on the topic, and it might therefore be time to open up the study of transatlanticism to new horizons to gain a better understanding of the exchanges between the continents.

\section{BIBLIOGRAPHY}

Adams, Amanda. Performing Authorship in the Nineteenth-Century Transatlantic Lecture Tour. Abingdon: Routledge, 2014. Print.

“Affairs in Europe. Our London Correspondence." The New York Herald. 12 June 1853. Web. 2 March 2018. 
Ammons, Elizabeth. "Stowe's Dream of the Mother-Savior. Uncle Tom's Cabin and American Women Writers Before the 1920s.” New Essays on Uncle Tom's Cabin. Ed. Eric J. Sundquist. Cambridge: Cambridge UP, 1993. 155-195. Print.

"Binnenland: Rotterdam, 5 februarij." Nieuwe Rotterdamsche Courant, 6 Feb 1867. Web. 2 March 2018.

Blake, David Haven. Walt Whitman and the Culture of American Celebrity. New Haven: Yale University Press, 2006. Print.

Boorstin, Daniel J. The Image: A Guide to Pseudo-Events in America. New York: Vintage Books, 2012. Print.

Buchanan, David. Acts of Modernity: The Historical Novel and Effective Communication, 1814-1901. Abingdon: Routledge, 2017. Print.

Carpentier, A. “Longfellow's jongste gedicht.” De Gids 22 (1858): 642-668. Web. 2 March 2018.

Claessens, Nathalie, and Hilde Van den Bulck. "A Severe Case of Disliking Bimbo Heidi, Scumbag Jesse and Bastard Tiger: Analysing Celebrities' Online Anti-fans.” The Ashgate Research Companion to Fan Cultures. Ed. Linda Duits, Koos Zwaan, and Stijn Reijnders. London and New York: Routledge, 2014. 63-76. Print.

Clark, Jennifer. The American Idea of England, 1776-1840. Transatlantic Writing. Abingdon: Routledge, 2013. Print.

"De Meibloem: Tooneelen en karakterschetsen uit Noord-Amerika." Vaderlandsche Letteroefeningen 93 (1853): 697-700. Web. 2 March 2018.

“De Slavernij, door Harriët Beecher Stowe.” Vaderlandsche Letteroefeningen 94 (1854): 761-764. Web. 2 March 2018.

DeSpain, Jessica. Nineteenth-Century Transatlantic Reprinting and the Embodied Book. Abingdon: Routledge, 2014. Print.

Dowling, David. Capital Letters: Authorship in the Antebellum Literary Market. Iowa City: U of Iowa P, 2009. Print.

Dzelzainis, Ella, and Ruth Livesey, eds. The American Experiment and the Idea of Democracy in British Culture, 1776-1914. Abingdon: Routledge, 2013. Print.

Finnerty, Páraic, and Mark Frost. “Editorial.” Critical Survey 27.3 (2015): 1-5. Web. 2 March 2018.

Finnerty, Páraic, and Rod Rosenquist. "Transatlantic Celebrity: European Fame in NineteenthCentury America.” Comparative American Studies 14.1 (2016): 1-6. Web. 2 March 2018.

Fisch, Audrey. "Uncle Tom and Harriet Beecher Stowe in England." The Cambridge Companion to Harriet Beecher Stowe. Ed. Cindy Weinstein. Cambridge: Cambridge UP, 2006. 96-112. Print.

Franssen, Gaston, and Rick Honings. Celebrity Authorship and Afterlives in English and American Literature. London: Palgrave Macmillan, 2016. Print.

Gossett, Thomas F. Uncle Tom's Cabin and American Culture. Dallas: Southern Methodist University Press, 1985. Print.

Ham, Laurens. "Occasional Writer, Sensational Writer: Multatuli as a Sentimental Benevolence Writer in the 1860s." Texts, Transmissions, Receptions: Modern Approaches to Narratives. Ed. André Lardinois et al. Leiden and Boston: Brill, 2014. 295-311. Print.

Hedrick, Joan D. Harriet Beecher Stowe: A Life. New York and Oxford: Oxford UP, 1994. Print. 
Helms, Whitney. Symbolic Capital and the Performativity of Authorship: The Construction and Commodification of the Nineteenth-Century Authorial Celebrity. Ph.D. Dissertation. U of Nebraska, 2013. Web. 2 March 2018.

Honings, Rick. De dichter als idool. Literaire roem in de negentiende eeuw. Amsterdam: Bert Bakker, 2016. Print.

Huisman, Marijke. Verhalen van vrijheid: autobiografieën van slaven in transnationaal perspectief, 1789-2013. Hilversum: Verloren, 2015. Print.

Hutchings, Kevin, and John Miller, eds. Transatlantic Literary Ecologies. Nature and Culture in the Nineteenth-Century Anglophone Atlantic World. Abingdon: Routledge, 2017. Print.

Inglis, Fred. A Short History of Celebrity. Princeton/Woodstock: Princeton UP, 2010. Print. Janse, Maartje. De afschaffers: Publieke opinie, organisatie en politiek in Nederland 1840-1880. Amsterdam: Wereldbibliotheek, 2007. Print.

Kohn, Denise, Sarah Meer, and Emily B. Todd, eds. Transatlantic Stowe. Harriet Beecher Stowe and European Culture. Iowa City: University of Iowa Press, 2006. Print.

Leo. “Bij onze buren: herinneringen.” De Gids 24 (1860): 81-110. Web. 2 Mar. 2018.

Lueck, Beth L., Brigitte Bailey, and Lucinda L. Damon-Bach, eds. Transatlantic Women: Nineteenth-Century American Women Writers and Great Britain. Durham: U of New Hampshire P, 2012. Print.

Manning, Susan, and Francis D. Cogliano, eds. The Atlantic Enlightenment. Abingdon: Routledge, 2008. Print.

Maudlin, Daniel, and Robin Peel, eds. The Materials of Exchange between Britain and North East America, 1750-1900. Abingdon: Routledge, 2013. Print.

Mentz, Steve, and Martha Elena Rojas, eds. The Sea and Nineteenth-Century Anglophone Literary Culture. Abingdon: Routledge, 2017. Print.

Newbury, Michael. Figuring Authorship in Antebellum America. Stanford: Stanford UP, 1997. Print.

Parfait, Claire. The Publishing History of Uncle Tom's Cabin. Aldershot/Burlington: Ashgate, 2007. Print.

Phegley, Jennifer, John Cyril Barton, and Kristin N. Huston, eds. Transatlantic Sensations. Abingdon: Routledge, 2012. Print.

Riewald, J. G., and J. Bakker. The Critical Reception of American Literature in the Netherlands 1824-1900: A Documentary Conspectus from Contemporary Periodicals. Amsterdam: Rodopi, 1982. Print.

Robbins, Sarah Ruffing. "Harriet Beecher Stowe, Starring as Benevolent Celebrity Traveler." Transatlantic Women: Nineteenth-Century American Women Writers and Great Britain. Ed. Beth L. Lueck, Brigitte Bailey and Linda L. Damon-Bach. Durham: U of New Hampshire P, 2012. 71-88. Print.

“Schaduwbeelden uit Suriname." Vaderlandsche Letteroefeningen 99 (1859): 223-228. Web. 2 Mar. 2018.

Schimmel, H. J. “Blikken in de werkelijkheid.” De Gids 17 (1853): 27-62. Web. 2 Mar. 2018.

S[chimmel], [H.J.] “Holland. Almanak voor 1854.” De Gids 18 (1854): 119-142. Web. 2 Mar. 2018. 
Spiritus Lenis en Asper, "Het letterkundig meteoor in het westen." De Tijdspiegel 10 (1853): 184-187. Print.

Stowe, Harriet Beecher. Herinneringen uit vreemde landen. Amsterdam: Wed. L. van Hulst en Zoon, 1855. Print.

Stowe, Charles Edward. The Life of Harriet Beecher Stowe: Compiled from her Letters and Journals. Boston: Houghton, 1889. Print.

“Uncle Tomitudes.” Putnam's Monthly Magazine 1 (1853): 97-102. Web. 2 March 2018.

Van der Meulen, M. E. "Een vlugtige blik op Noord-Amerika en een boek dat daar verscheen." Pantheon 1 (1853): 129-145. Print.

Van Krieken, Robert. Celebrity Society. London/New York: Routledge, 2012. Print.

Virgil. The Works of Virgil, Translated Into English Prose, etc., in Two Volumes: Volume II.

London: printed for Geo. B. Whittaker etc., 1826. Print.

Visser, Arnoud. In de gloria: Literaire roem in de Renaissance. The Hague: Algemeen Nederlands Verbond, 2013. Print.

Vollaro, Daniel R. "Lincoln, Stowe, and the 'Little Woman/Great War' Story. The Making, and Breaking, of a Great American Anecdote." Journal of the Abraham Lincoln Association 30.1 (2009): 18-34. Web. 2 March 2018.

Weber, Brenda R. Women and Literary Celebrity in the Nineteenth Century: The Transatlantic Production of Fame and Gender. London and New York: Routledge, 2012. Print.

Wood, Marcus. Blind Memory: Visual Representations of Slavery. Manchester: Manchester University Press, 2000. Print.

YY. "Engelsche en Amerikaansche dames-strijd, naar aanleiding van Uncle Tom's Cabin." Pantheon 1 (1853): 93-95. Print.

Z[immerman], Johan C. "Nieuwe Schetsen en Verhalen van Mrs. Harriet Beecher Stowe, schrijfster van de Negerhut en de Meibloem.” De Gids 18 (1854): 141-142. Web. 2 March 2018.

\section{NOTES}

1. All ten books in the Ashgate Series in Nineteenth Century Transatlantic Studies focus virtually entirely on cultural phenomena in Britain and the US (Adams; Buchanan; Clark; DeSpain; Dzelzainis and Livesey; Hutchings and Miller; Manning and Cogliano; Maudlin and Peel; Mentz and Rojas; Phegley, Barton, and Huston).

2. Lueck, Bailey, and Damon-Bach is unique in consequently distinguishing "Britain" from "Europe."

3. Jewett \& Co. “Advertisement." The New York Independent. May 20, 1852.

http://utc.iath.virginia.edu/reviews/read12at.html.

Jewett \& Co., “[Advertisement in back pages of Uncle Tom's Cabin].” Boston: John P. Jewett, 1852.

http://utc.iath.virginia.edu/reviews/rehp.html

4. For examples, see http://utc.iath.virginia.edu/tomituds/tohp.html.

5. The calendar can be found at http://utc.iath.virginia.edu/tomituds/toadsf.html; the poster is depicted in Gossett (no page numbers). The association of Stowe with Lincoln is a well-known trope from around the 1890s: in 1896, the year of Stowe's death, Atlantic Monthly was the first to spread the apocryphal and evidently inaccurate anecdote that Lincoln in 1862, in the midst of the 
American Civil War, would have said to Stowe: "Is this the little woman who made the great war?" (Vollaro).

6. The engraving is part of the Multatuli Collection, in the University of Amsterdam library collection (code Hs. XLV E AM 1059 a). It is difficult to compare the dissemination of visual portraits of Stowe in the Netherlands and in the English-speaking world. It seems that in the UK, portraits were already included in the earliest 'people's editions' in 1853 (Helms 81). The first Dutch edition of 1853, which was fairly expensive, did include a portrait of the author, but it is hard to reconstruct in what numbers pictures of Stowe were circulating in 1850s Holland.

7. The West Indies (Surinam and the Dutch Antilles) constituted a fourth region, though considerably smaller in the number of readers.

8. All Dutch newspaper sources in this chapter were consulted using http:// www.delpher.nl, a large electronic media archive.

9. De Tijd, March 27, 1872 (rumor); Algemeen Handelsblad, March 30, 1872 (rectification); De locomotief, May 15, 1872 (rumor). The news media in the Indies may have extracted news facts from Dutch sources, which took weeks or months to arrive.

\section{ABSTRACTS}

This article questions the supposed pervasive celebrity of the American author Harriet Beecher Stowe in Europe in the nineteenth century, and investigates her authorial status in the Netherlands in the mid-1850s. To what extent could she be considered a celebrity in the Netherlands in this period? The article pays attention both to the institutional and to the ideological situation, which can either facilitate or hinder the development of a so-called "celebrity society," and shows that textual representations of Stowe did indeed circulate, but that this circulation did not take on the massive scale that seems necessary for a celebrity status. Whereas Uncle Tom's Cabin was, by Dutch standards, an incredible success, journalists were only marginally aware of the authorial figure of Stowe herself. This was in part a result of the lack of a professional literary and journalistic infrastructure in the Netherlands. From an ideological point of view, the phenomenon of literary celebrity was a controversial one in the nineteenth-century Netherlands, hampering the emergence of a celebrity society. Together, these findings help us to consider the existence of a possible "transatlantic" Stowe cult in a different light: in the peripheral Netherlands, such a cult did not emerge easily.

\section{INDEX}

Schlüsselwörter: celebrity authorship, transatlanticism, history of institutions, media history, literary reception, Harriet Beecher Stowe 


\section{AUTHOR}

\section{LAURENS HAM}

Laurens Ham is Assistant Professor in Modern Dutch Literature at Utrecht University, the Netherlands. In 2015, he published a book, based on his PhD research, about Dutch writers between 1820-1970 combining an "autonomous" self-presentation with political critique. Currently, he works on a cultural history of Dutch literary policy since the 1960s, focusing on the ways in which authors have shaped and influenced the policy climate. 